\title{
Aerodynamic performance of long span steel truss bridges in Indonesia
}

\author{
Suangga Made $^{1, *}$ and Irpanni Herry ${ }^{2}$ \\ ${ }^{1}$ Civil Engineering Department, Bina Nusantara University, Jl. K. H. Syahdan No. 9 Jakarta Indonesia \\ ${ }^{2}$ Ministry of Public Work and Housing, Jl. Pattimura No. 20 Jakarta Indonesia.
}

\begin{abstract}
Indonesia is the world's largest archipelago with many major rivers in the big islands of Sumatera, Kalimantan, and Java. As part of its road network, major bridges are constructed to cross these rivers. Considering the span of the bridges and its aesthetic point of view, the application of Long Span Steel Truss Bridges in Indonesia is very popular among others. Its span varies from 70 to 270 meters in length. For long span bridges, aerodynamics is an important aspect for the design and construction of the bridges. In order to ensure the stability of the bridges against the aerodynamic effect of the wind, wind tunnel study and test has been conducted for most of the bridges. This paper presents the parameter and characteristic of several Long Span Steel Truss Bridges in Indonesia, i.e. Tayan Kapuas Bridge, Musi VI Bridge, New Kutai Kartanegara Bridges and Teluk Mesjid Bridge. The bridges will be assessed against BD 49/01. Parameters and assessment results are then compared with wind tunnel results.
\end{abstract}

\section{Introduction}

Indonesia is the world's largest archipelago country. The main islands are Java, Kalimantan, Sumatera, Sulawesi, and Papua. Indonesia has many rivers and the majority of Indonesia's population lives near water, both on the coast or along rivers and lake shores. Land transportation is a main mode of transportation in Indonesia. Therefore, in providing a reliable transportation system as part of the road network system, major bridges need to be constructed to cross Indonesia's main rivers.

By definition, a bridge is considered as a long span bridge when the span is larger than $100 \mathrm{~m}$. Many long span bridges have been constructed or are in the planning stage, which include suspension bridge, cable stayed bridge, steel truss arch bridge and concrete balance cantilever bridge. Considering the span of the bridges and its aesthetic point of view, application of Long Span Steel Truss Bridges in Indonesia is very popular among others. Its span varies from 70 to 270 meters in length.

Long span bridges are flexible structures in which wind effects play a dominant role in the design process. Since the failure of the Tacoma Narrow Bridge in 1940, aerodynamic stability has become one of the most important factors in the design of a long span bridge.

\footnotetext{
*Corresponding author: suangga@binus.edu
} 
Wind effects on long bridges can lead to instability of the whole bridge structure. Therefore, consideration of wind effects on the whole structure starting from its preliminary design is important in order to get the appropriate design configuration.

Table 1 shows the list of long span steel truss bridges with main span of $100 \mathrm{~m}$ or more which have been built and are planned to be built in Indonesia

Table 1. List of long span steel truss bridge in Indonesia with main span of $100 \mathrm{~m}$ or more.

\begin{tabular}{|c|c|c|c|c|}
\hline No & Bridge Name & Location & $\begin{array}{c}\text { Completion } \\
\text { Year }\end{array}$ & Main Span length \\
\hline 1 & Rumbai Jaya & Indragiri Hilir & 2003 & $150 \mathrm{~m}$ \\
\hline 2 & Kahayan Kota & Palangkaraya & 2005 & $150 \mathrm{~m}$ \\
\hline 3 & Martadipura & Kukar - Kota Bangun & 2006 & $200 \mathrm{~m}$ \\
\hline 4 & Kahayan Hulu & Gunung Mas & 2006 & $160 \mathrm{~m}$ \\
\hline 5 & Musi II Tebing Tinggi & Empat Lawang & 2007 & $100 \mathrm{~m}$ \\
\hline 6 & Bojonegoro / Malo & Bojonegoro & 2007 & $128 \mathrm{~m}$ \\
\hline 7 & Merdeka & Murung Raya & 2008 & $100 \mathrm{~m}$ \\
\hline 8 & Rumpiang & Barito Kuala & 2008 & $200 \mathrm{~m}$ \\
\hline 9 & Mahakam Ulu & Samarinda & 2008 & $200 \mathrm{~m}$ \\
\hline 10 & Batanghari 2 & Jambi & 2010 & $150 \mathrm{~m}$ \\
\hline 11 & Kalahien & Barito Selatan & 2010 & $200 \mathrm{~m}$ \\
\hline 12 & Teluk Mesjid & Kabupaten Siak & 2012 & $250 \mathrm{~m}$ \\
\hline 13 & Muara Sabak & Tanjung Jabung Timur & 2012 & $150 \mathrm{~m}$ \\
\hline 14 & Ogan I Pelengkung & Palembang & 2013 & $160 \mathrm{~m}$ \\
\hline 15 & Gugus & Tanjung Pinang & 2013 & $120 \mathrm{~m}$ \\
\hline 16 & Kali Mujur / Selowangi & Lumajang & 2013 & $120 \mathrm{~m}$ \\
\hline 17 & New Kutai Kartanegara & Kukar - Tenggarong & 2015 & $270 \mathrm{~m}$ \\
\hline 18 & Tayan Kapuas & Tayan & 2016 & $200 \mathrm{~m}$ \\
\hline 19 & Musi VI & Palembang & 2018 & $200 \mathrm{~m}$ \\
\hline 20 & Mahakam I Duplikasi & Samarinda & $\begin{array}{c}\text { under } \\
\text { construction }\end{array}$ & $220 \mathrm{~m}$ \\
\hline
\end{tabular}

This paper presents dynamic wind consideration during the design stage, as well as the parameters and characteristics of several Long Span Steel Truss Bridges in Indonesia. The performance of the bridges is assessed against BD 49/01, the British Standard for Design rules for aerodynamic effects on Bridges. The respective parameters and the assessment results are compared with the results obtained from wind tunnel tests.

Due to the availability of DED related to aerodynamic requirement, only the following bridges are considered in this paper, i.e. Tayan Kapuas Bridge, Musi VI Bridge, New Kutai Kartanegara Bridge, and Teluk Mesjid Bridge. 


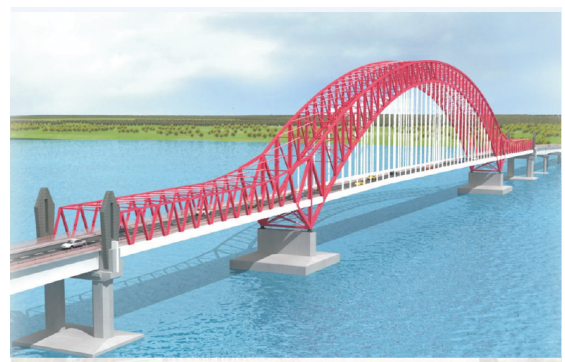

Tayan Kapuas Bridge

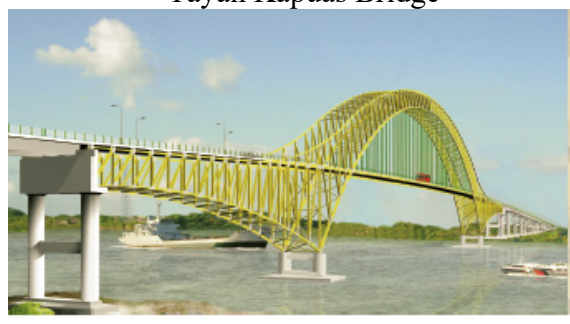

Teluk Mesjid Bridge

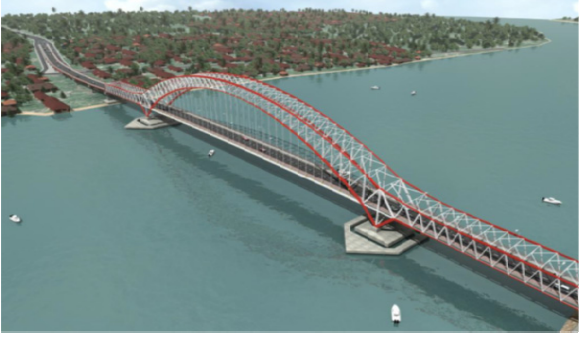

Musi VI Bridge

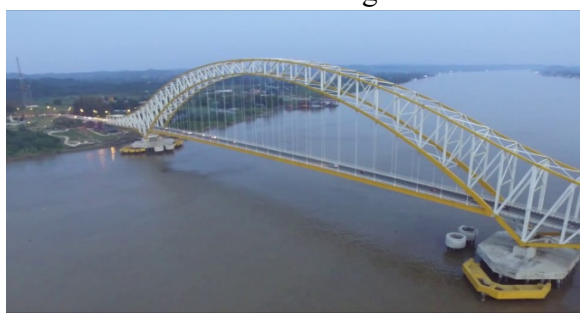

New Kutai Kartanegara Bridge

Fig. 1. Long span truss bridges considered in this study.

\section{Wind consideration on long span bridge}

Even though the oscillation of the bridge under wind loads has been observed in many cases during the early history of the suspension bridge and some of the failures of bridges have also been experienced, the answer to such problems was still unclear until the collapse of the Tacoma Narrow Bridge by a moderate wind load. Its collapse resulted in rigorous research being performed on the aerodynamic stability of bridges.

The construction and design of suspension bridges is undoubtedly influenced by the failure of the Tacoma Narrows Bridge under a wind of moderate intensity on November 7, 1940 . With the recorded wind speed of $42 \mathrm{mph}(18.8 \mathrm{~m} / \mathrm{s})$, the bridge developed vertical wave motions. Its motion then changed so that the main span vibrated with two cables out of phase with a node at mid span. The motion resulted in a twisting of the roadway, one side going down as the other side went up.

Although the causes of the failure were unclear at the moment of the accident, it is now understood that the failure was due to a single degree of freedom of torsional flutter caused by wind driven self-excited force. Since then, new criteria for long span bridge have been introduced. The failure of the Tacoma Narrow Bridge shows that the criteria previously considered for stiffness against static loads do not apply in the analysis of flexible bridges under wind forces. It has become the starting point of the studies on bridge aeroelasticity, which involves significant mutual interaction between structural motions and aeroelastic forces. The design of flexible bridges must assure that the structure is stable under dynamic effect of wind loads as given in Table 2 . 
Table 2. Classification of wind effect on structures.

\begin{tabular}{|c|c|c|c|}
\hline & \multicolumn{3}{|c|}{ Effect of time-average wind pressure, wind force } \\
\hline \multirow[t]{2}{*}{ Static } & \multirow{2}{*}{$\begin{array}{c}\text { Static } \\
\text { instability }\end{array}$} & \multicolumn{2}{|c|}{ Divergence } \\
\hline & & \multicolumn{2}{|c|}{ Lateral Buckling } \\
\hline \multirow[t]{5}{*}{ Dynamic } & \multirow{4}{*}{$\begin{array}{l}\text { Dynamic } \\
\text { Instability }\end{array}$} & Galloping & \multirow{3}{*}{$\begin{array}{l}\text { Divergent } \\
\text { Amplitude } \\
\text { Response }\end{array}$} \\
\hline & & Torsional flutter & \\
\hline & & Coupled Flutter & \\
\hline & & \multirow{2}{*}{ Vortex excitation / low speed flutter } & \multirow{2}{*}{$\begin{array}{c}\text { Limited amplitude } \\
\text { Response }\end{array}$} \\
\hline & Turbulence response (gust, buffeting) & & \\
\hline
\end{tabular}

When a structure is exposed to wind, the fluctuating wind velocity translates into fluctuating pressure, which in turn produces a time-variable response of the structure. Buffeting is defined as the unsteady loading of a structure by velocity fluctuations in the oncoming flow. The buffeting response is caused by wind turbulence. It may lead to structural fatigue and an inconvenient effect to the vehicle.

Flutter is a phenomenon that may occur when a structure is subjected to aerodynamic forces. It occurs not only in aircraft but also in buildings, power lines, road signs and bridges. Flutter is an oscillation caused by significant mutual interaction between structural motions and aeroelastic forces. When the airspeed increases, the energy added in each oscillation to the structure by the aerodynamic forces increases. At some speed, the damping of the structure may be insufficient to absorb the energy increase from the aerodynamic load and the amplitude of the harmonic oscillations will grow until the structure breaks

When a fluid flows past a bluff body, such as a bridge deck or bridge hanger, it will result in the periodic shedding of vortices into the body's wake for all but the lowest flow speeds. This process gives rise to oscillatory lift and drag forces which, if the body is compliant or elastically is supported, can result in Vortex-Induced Vibrations

At the present time, the best procedure to predict the response of bridge structures to wind is a full model experiment in the wind tunnel in which the site conditions are simulated as close as possible. In fact, this procedure has been successfully applied to bridge projects in the past.

Long span steel truss bridges are susceptible to wind-induced vibration problems. The bridge deck is prone to flutter, buffeting or vortex-induced vibration. The bridge's hangers are also prone to dynamic wind vibration. Even though the excessive vibration of hangers has been found in Tayan Kapuas Bridge in Kalimantan, Indonesia, this paper will only focus on the performance of the bridge deck.

\subsection{Characteristics of the bridge deck}

Selection of the structural configuration as a result of preliminary design process is an important step in the long span bridge project design process. Based on such configuration, a more detailed analysis including the complicated processes such as wind tunnel tests shall be conducted. In a long span bridge, different configuration results in a different resistance against wind actions, so does the total cost; this is the main concern of this paper.

The weight, stiffness, and especially the shape of the cross section of a bridge deck determines the stability of the bridge in the wind. Subtle changes to the cross section of the bridge affect the stability of the bridge when subjected to strong winds.

During the preliminary design process, the total length of the bridge is a given factor based on the geographical condition of the site. The parameters commonly used to indicate bridge configuration which affect bridge stability are the shape of bridge deck, weight of the bridge deck, width ratio of the bridge deck, depth ratio of the bridge deck and stiffness of the bridge in term of frequencies 


\subsection{Predicting bridge instability based on frequency ratio}

A simple method to predict the onset velocity for flutter instability has been developed by Selberg based on the Bleich approach. He related the onset velocity $V_{\text {cr }}$ for a particular bridge deck to the equivalent Bleich flat plate flutter velocity, $\mathrm{V}_{\mathrm{F}}$ by the relation:

$$
V_{c r}=k V_{F}
$$

Where $k$ is a constant of proportionality that depends only on the deck geometry and the wind angle $\alpha$. Selberg has given experimental values of $k$ for a variety of road deck sections. He derived an empirical equation for $\mathrm{V}_{\mathrm{F}}$ based on Bleich's result, as follows:

$$
V_{F}=0.44 B \omega_{\alpha}\left[\left(1-\frac{\omega_{h}}{\omega_{\alpha}}\right)^{2} \frac{v^{0.5}}{\mu}\right]^{0.5}
$$

where

$$
\begin{gathered}
v=8\left(\frac{r}{B}\right)^{2} \\
\mu=\frac{\pi \rho B^{2}}{2 w} \\
r=\sqrt{\frac{\Theta}{m}}
\end{gathered}
$$

Where $\mathrm{B}$ denotes the width of the bridge, $\omega_{\mathrm{h}}$ and $\omega_{\alpha}$ are bending and torsional natural frequency, $\Theta$ is the bridge deck equivalent of polar mass, $m$ is mass of the bridge, $\rho$ is air density and $\mathrm{w}$ is the bridge deck's equivalent mass.

The equation above illustrates the importance of the frequency ratio $\omega_{\mathrm{h}} / \omega_{\alpha}$. As such, when the frequency ratio becomes unity, the values of $\mathrm{V}_{\mathrm{F}}$ and $\mathrm{V}_{\mathrm{cr}}$ become zero.

\subsection{Aerodynamic susceptibility based on BD 49/01 design rules for aerodynamic effects on bridges}

According to BD 49/91, the aerodynamic susceptibility parameter, $\mathrm{P}_{\mathrm{b}}$, shall be derived in order to categorise the structure using the equation [1]

$$
P_{b}=\left(\frac{\varphi b^{2}}{m}\right)\left(\frac{16 V^{2}}{b L f_{B}^{2}}\right)
$$

Where $\rho$ is the density of the air $\left(\mathrm{kg} / \mathrm{m}^{3}\right), \mathrm{b}$ is the overall width of the bridge deck $(\mathrm{m})$, $\mathrm{m}$ is the mass per unit length of the bridge $(\mathrm{kg} / \mathrm{m}), \mathrm{V}$ is the hourly mean wind speed at the bridge deck $(\mathrm{m} / \mathrm{s}), \mathrm{L}$ is the length of the relevant maximum span of the bridge and $\mathrm{f}_{\mathrm{B}}$ is the natural frequency in bending.

Bridges are considered to have insignificant effects of all forms of aerodynamic excitation when $\mathrm{P}_{\mathrm{b}}<0.04$. Bridges having $0.04 \leq \mathrm{P}_{\mathrm{b}} \leq 1.00$ shall be considered to be within the scope of these rules, provided the geometric constraints of the deck are satisfied and 
considered adequate with regard to each potential types of excitation. Bridges with $\mathrm{P}_{\mathrm{b}}>1.00$ shall be considered to potentially be very susceptible to aerodynamic excitation.

In 2014, the Indonesian Ministry of Public Works developed a draft of Guide of Wind Tunnel Test for Bridges [6]. Although this document was yet to become official until 2018, some of the wind tunnel tests had followed the criteria in the draft document [8].

\subsection{Wind tunnel test}

Since the Tacoma Narrow Bridge disaster, wind tunnel tests have become an important tool in the investigation of aeroelastic stability. This wind tunnel test is performed either on full models comprising the entire cable supported bridge with stiffener girder, pylon and cable system, or on section models of relatively small segment of stiffener girder. A full model offers the advantage of the most realistic reproduction of the interaction between the aerodynamic forces and all parts of the structure, but it requires a very high degree of accuracy in manufacturing the model. Therefore, it's very expensive to use the full model, yet difficult to make modification.

A section model consists of a segment of deck girder usually in the scale of 1:25 and $1: 100$, thus less demanding in manufacturing accuracy. Moreover, it makes the section model easier to modify to test the effects of different configurations.

\section{Data and analysis}

\subsection{Cross section and sectional characteristic}

Figure 2 show the cross section of the considered bridges. For the bridges considered, the bridge deck structure mostly consists of concrete slab, steel longitudinal and transversal beams.

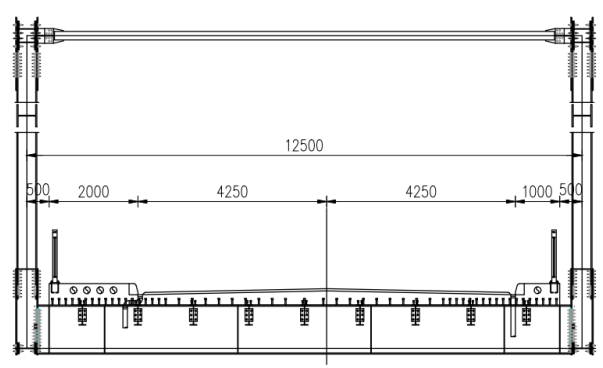

Tayan Kapuas Bridge

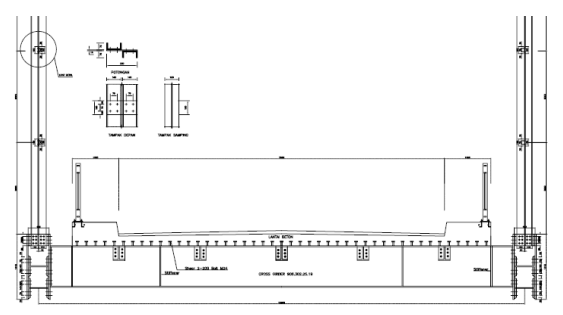

Teluk Mesjid Bridge

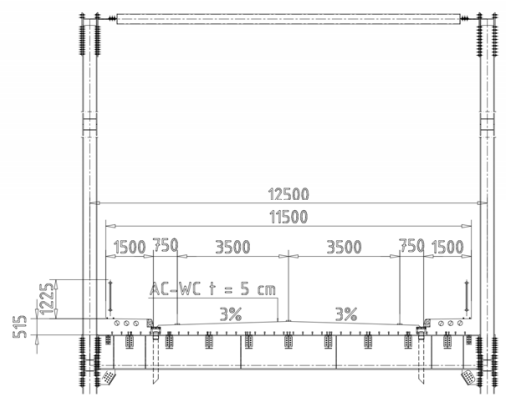

Musi VI Bridge

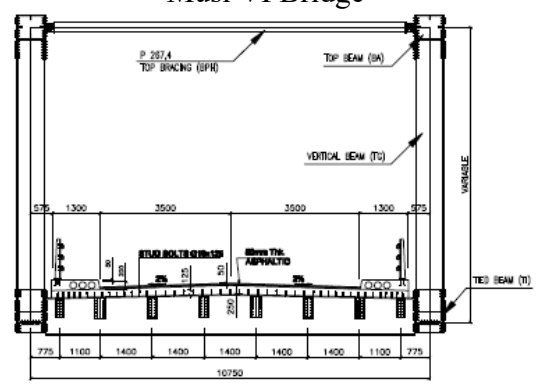

Kutai Kartanegara (New) Bridge

Fig. 2. Cross Section of long span truss bridges considered in this study. 
Sectional characteristics of the bridges are presented in Table 3.

Table 3. Sectional characteristics of the bridges.

\begin{tabular}{|c|c|c|c|c|c|c|c|}
\hline No & Bridge Name & $\begin{array}{c}\text { Bridge } \\
\text { span } \\
\mathbf{( m )}\end{array}$ & $\begin{array}{c}\text { mass } \\
\text { per } \\
\text { unit } \\
\text { length } \\
\mathbf{( k g / m )}\end{array}$ & $\begin{array}{c}\text { width of } \\
\text { the deck } \\
\mathbf{( m )}\end{array}$ & $\begin{array}{c}\text { depth } \\
\text { of the } \\
\mathbf{d e c k} \\
\mathbf{( m )}\end{array}$ & $\begin{array}{c}\text { span to } \\
\text { width } \\
\text { ratio }\end{array}$ & $\begin{array}{c}\text { span to } \\
\text { depth } \\
\text { ratio }\end{array}$ \\
\hline 1 & Tayan Kapuas [3] & 200 & 14,347 & 12.95 & 2.00 & 15.44 & 100.00 \\
\hline 2 & Musi VI [7] & 200 & 14,625 & 12.9 & 1.94 & 15.50 & 103.09 \\
\hline 3 & Teluk Mesjid [2] [4] & 250 & 11,785 & 10.45 & 2.32 & 23.92 & 107.76 \\
\hline 4 & $\begin{array}{c}\text { New Kutai Kartanegara } \\
{[5]}\end{array}$ & 270 & 10,200 & 11.54 & 1.35 & 23.40 & 200.00 \\
\hline
\end{tabular}

\subsection{Dynamic characteristic of the bridges}

As described in equation 2, the frequency ratio is an important aspect in predicting the flutter onset wind speed. As the ratio $\omega_{\mathrm{h}} / \omega_{\alpha}$ becomes unity, the value of $\mathrm{V}_{\mathrm{F}}$ and $\mathrm{V}_{\mathrm{cr}}$ become zero. Table 4 shows the frequencies and frequency ratios of the bridges.

Table 4. Dynamic characteristics of the bridges

\begin{tabular}{|c|c|c|c|c|c|c|}
\hline No & Bridge Name & $\begin{array}{c}\text { Length of } \\
\text { Main Span } \\
(\mathbf{m})\end{array}$ & $\begin{array}{c}\text { Mass per } \\
\text { Unit } \\
\text { Length } \\
\mathbf{( k g} / \mathbf{m})\end{array}$ & $\begin{array}{c}\omega_{h} \\
(\mathbf{H z})\end{array}$ & $\begin{array}{c}\omega_{\alpha} \\
(\mathbf{H z})\end{array}$ & $\begin{array}{c}\text { Frequency } \\
\text { Ratio } \\
\left(\omega_{h} / \omega_{\alpha}\right)\end{array}$ \\
\hline 1 & Tayan Kapuas [3] & 200 & 14,347 & 0.760 & 1.220 & 1.605 \\
\hline 2 & Musi VI [7] & 200 & 14,625 & 0.750 & 0.860 & 1.147 \\
\hline 3 & Teluk Mesjid [2] [4] & 250 & 11,785 & 0.794 & 1.163 & 1.465 \\
\hline 4 & $\begin{array}{c}\text { New Kutai Kartanegara } \\
{[5]}\end{array}$ & 270 & 10,200 & 0.727 & 0.734 & 1.010 \\
\hline
\end{tabular}

\subsection{Design wind speed}

The majority of all design application in wind engineering concern the lifetime performance of the structure, hence extreme wind data is more relevant to use in analysis than the observed wind data. The design application of wind loads is related to the strongest wind expected in the lifetime of the structure. Thus, the focus is on the extreme value of wind speed.

Maximum wind speed values depend on the averaging interval. As the length of the averaging interval decreases, the maximum wind speeds corresponding to such length increase. Therefore, it is necessary to refer to the data under identical or equivalent conditions.

Various researches have indicated that analysis of the largest wind data of extreme wind speeds int well-behaved climates is better modelled by the Gumbel distribution (Extreme value type I) than by the Extreme value type II distribution. The basic wind speed is then defined as a speed corresponding to a specific value of $\mathrm{p}$ of the Cumulative Distribution Function or, equivalently, to specific recurrence interval N. 
For many cases, the data available for predicting the design speed is not large enough for the analysis. To obtain additional data, distribution methods in which its applicability was tested for a large number of U.S weather stations may be used to infer the probabilistic behaviour of extreme wind from data consisting of the largest monthly wind speed recorded over three years or longer.

Unfortunately, no specific analysis of design wind speed values is available for this analysis. BD 49/01 indicates that in the absence of wind speed data, a value of $20-40 \mathrm{~m} / \mathrm{s}$ hourly mean wind speed may be adopted for initial analysis [1].

\subsection{Aerodynamic susceptibility based on BD 49/01}

Based on sectional characteristics, bridge span, deck weight and natural frequency parameters, the susceptibility of the bridge to dynamic wind has been analysed based on BD 49/01. The value of $\mathrm{P}_{\mathrm{b}}$ for steel truss bridges considered in this study is presented in Table 5.

Table 5. Susceptibility of the bridges to dynamic wind action.

\begin{tabular}{|c|c|c|c|c|c|c|c|}
\hline No & Bridge Name & $\begin{array}{c}\text { bridge } \\
\text { main } \\
\text { span } \\
(\mathbf{m})\end{array}$ & $\begin{array}{c}\text { the mass } \\
\mathbf{p e r} \text { unit } \\
\mathbf{l e n g t h} \\
\mathbf{( k g} / \mathbf{m})\end{array}$ & $\begin{array}{c}\omega_{h} \\
(\mathbf{H z})\end{array}$ & $\begin{array}{c}\mathbf{P}_{\mathbf{b}} \\
(\mathbf{V = 2 0} \\
\mathbf{m} / \mathbf{s})\end{array}$ & $\begin{array}{c}\mathbf{P}_{\mathbf{b}} \\
\mathbf{( V = 3 0} \\
\mathbf{m} / \mathbf{s})\end{array}$ & $\begin{array}{c}\mathbf{P}_{\mathbf{b}} \\
\mathbf{( V = 4 0} \\
\mathbf{m} / \mathbf{s})\end{array}$ \\
\hline 1 & Tayan Kapuas & 200 & 14,347 & 0.760 & 0.061 & 0.138 & 0.245 \\
\hline 2 & Musi VI & 200 & 14,625 & 0.750 & 0.061 & 0.138 & 0.246 \\
\hline 3 & Teluk Mesjid & 250 & 11,785 & 0.794 & 0.044 & 0.099 & 0.176 \\
\hline 4 & New Kutai Kartanegara & 270 & 10,200 & 0.727 & 0.062 & 0.140 & 0.249 \\
\hline
\end{tabular}

Table 4 indicates all of the bridges that have $0.04 \leq \mathrm{P}_{\mathrm{b}} \leq 1.00$. This means that the geometric constraints of deck geometric shall be satisfied and shall be adequate with regard to each potential types of excitation if they satisfy the relevant criteria. This range is valid for $20 \mathrm{~m} / \mathrm{s}-40 \mathrm{~m} / \mathrm{s}$ hourly mean speed.

\subsection{Result of wind tunnel test}

The results of the wind tunnel test for the bridges studied are summarized in Table 6 .

Table 6. Result of wind tunnel test.

\begin{tabular}{|c|c|c|c|c|c|c|}
\hline No & Bridge Name & $\begin{array}{c}\text { Length of } \\
\text { Main } \\
\text { Span }(\mathbf{m})\end{array}$ & $\begin{array}{c}\text { frequency } \\
\text { ratio } \\
\left(\omega_{h} / \omega_{\alpha}\right)\end{array}$ & $\begin{array}{c}P_{b} \mathbf{( V = 4 0} \\
\mathbf{m} / \mathbf{s})\end{array}$ & $\begin{array}{c}\text { Vortex } \\
\text { Induced } \\
\text { Vibration }\end{array}$ & $\begin{array}{c}\text { Flutter } \\
\text { Speed } \\
\mathbf{( m / s})\end{array}$ \\
\hline 1 & $\begin{array}{c}\text { Tayan } \\
\text { Kapuas }\end{array}$ & 200 & 1.605 & 0.245 & $\begin{array}{c}\text { vertical at } 25.3 \\
\mathrm{~m} / \mathrm{s} \\
\text { and torsional at } \\
36.9 \mathrm{~m} / \mathrm{s}[3]\end{array}$ & $\begin{array}{c}\text { No flutter } \\
(149 \mathrm{~m} / \mathrm{s}) \\
{[3]}\end{array}$ \\
\hline 2 & Musi VI & 200 & 1.147 & 0.246 & $\begin{array}{c}\text { vertical at } 10.75 \\
\mathrm{~m} / \mathrm{s}[7]\end{array}$ & $56 \mathrm{~km} / \mathrm{s}[7]$ \\
\hline 3 & Teluk Mesjid & 250 & 1.465 & 0.176 & - & $\begin{array}{c}\text { No flutter } \\
{[2][4]}\end{array}$ \\
\hline 4 & $\begin{array}{c}\text { New Kutai } \\
\text { Kartanegara }\end{array}$ & 270 & 1.010 & 0.249 & $\begin{array}{c}\text { vertical at } 15 \\
\text { m/s only at low } \\
\text { structural } \\
\text { damping [5] }\end{array}$ & $\begin{array}{c}\text { No flutter } \\
{[5]}\end{array}$ \\
\hline
\end{tabular}


Based on Table 5, parameter $\mathrm{P}_{\mathrm{b}}$ clearly indicates the susceptibility of the bridges to dynamic wind action. Herein, the frequency ratio is unable to indicate the stability of the bridge to flutter. In the case of the new Kutai Kartanegara Bridge, eventhough the ratio almost equals to 1 , no flutter has been found.

\section{Conclusions and recommendations}

Based on the above data and the analysis of 4 long span steel truss bridges in Indonesia, the following conclusions and recommendations can be drawn:

1. Susceptibility of the Bridges to dynamic wind action $\mathrm{P}_{\mathrm{b}}$ has been a good indicator to indicate the stability of the long span steel truss to dynamic wind.

2. Eventhough steel truss arch bridges are categorized as long span bridges, a susceptibility check of the Bridges using BD 89/01 indicated that the long span steel truss bridge structure of up to $270 \mathrm{~m}$ span is less susceptible to aerodynamic excitation and therefore wind tunnel analysis is not mandatory.

3. The frequency ratio is unable to be used to indicate the stability of the bridge to flutter.

4. The results of wind tunnel tests agree well with the susceptibility of the bridges to dynamic wind action analysis where the critical flutter speed is much higher or there is no flutter

5. Design wind speed is of a critical parameter for long span bridge design, thus such kind of data and analysis need to be available.

6. Considering the present result of the wind tunnel test, application of longer steel truss bridges is possible in the future, noting that dynamic wind performance needs to be carefully examined.

\section{References}

1. BD 49/01 Design Rules for Aerodynamic Effects on Bridges (2001)

2. M. Eaddy, W. H. Melbourne, Wind Tunnel Tests on a Sectional Model of The Teluk Masjid Bridge Indonesia, MEL Consultant Report, (2008)

3. Laboratorium Aero-gas Dinamika dan Getaran, Laporan Pengujian Sectional Model Jembatan Tayan-Kapuas, (2008)

4. Departemen Pekerjaan Umum Direktorat Jenderal Bina Marga Direktorat Bina Teknik Sub Direktorat Teknik Jembatan, Laporan Analisa Mode Shape Jembatan Teluk Mesjid Provinsi Riau, (2008)

5. PT Adiyasa Desicon, Report on Wind Tunnel Check Jembatan Kutai KartanegaraLaporan Akhir, (2013)

6. Departemen Pekerjaan Umum Direktorat Jenderal Bina Marga, Draft Pedoman Pelaksanaan Uji Angin Pada Jembatan, (2014)

7. Balai Besar Teknologi Aerodinamika Aeroelastika, dan Aeroakustika (BBTA3) BPPT, Laporan Pengujian Terowongan Angin Jembatan Musi VI, (2016)

8. R. Permana, M. Andika, Syariefatunnisa, E. Risdhiawan, B. Hermawan, I. Noordiana, Wind Tunnel Test of Musi VI Bridge, Proceedings of the 3rd International Conference on Construction and Building Engineering, 020005-1-020005-7 (2017) 